\title{
Serotonin and Hippocampal Neurogenesis
}

\author{
Elizabeth Gould, Ph.D.
}

The dentate gyrus continues to produce new granule neurons well into adulthood. This has been demonstrated for many mammalian species, from rodents to primates. The proliferation of granule cell precursors can be suppressed by stressful experiences, presumably via adrenal steroids. Recent evidence suggests that serotonin can enhance the production of new neurons via activation of the $5 H T 1 A$ receptor. These results present the possibility that the inhibitory effects of stress on granule cell production may be prevented by 5 HT $1 A$ receptor agonists.

[Neuropsychopharmacology 21:46S-51S, 1999]

(C) 1999 American College of Neuropsychopharmacology.

Published by Elsevier Science Inc.
KEY WORDS: Neurogenesis; 5 HT1A receptor; Dentate gyrus; Hippocampus; Granule cell; Stress

The role of the molecule serotonin, or 5-hydroxytryptamine, in neurotransmission has been recognized for decades. More recent studies have explored the possibility that serotonin may have structural effects on the brain both during development and in adulthood (Mazer et al. 1997; Yan et al. 1997; Watanabe et al. 1992). These studies have predominantly focused on the role of serotonin in mediating the structure of the adult brain. Our recent studies have identified a new role for serotonin in mediating the structure of the adult brain. We have found that neurogenesis in the adult mammalian dentate gyrus is enhanced by activation of serotonergic receptors (Jacobs et al. 1998).

\section{THE PRODUCTION OF HIPPOCAMPAL GRANULE NEURONS CONTINUES INTO ADULTHOOD}

In the majority of mammalian brain regions, the production, migration and death of neurons are restricted

From the Department of Psychology, Princeton University, Princeton, $\mathrm{NJ}$

Address correspondence to: Dr. E. Gould, Princeton University, Department of Psychology, Princeton, NJ 08544.

Received December 10, 1998; revised March 30, 1999; accepted March 31, 1999. to gestation and are complete within several days. Once this developmental phase ends, neurons differentiate and these processes do not continue. In contrast, the granule cell layer $(\mathrm{gcl})$ of the dentate gyrus is formed during an extended period that begins during gestation and continues into adulthood. During the embryonic period, granule cell precursors originate from the wall of the lateral ventricles and migrate along radial glial fibers to the developing hippocampus (Rickmann et al. 1987; Schlessinger et al. 1975; Altman and Bayer 1990a, b). Many of these cells die while migrating toward the forming dentate gyrus (Gould 1994). From the late embryonic period through the first postnatal week in the rat, granule neurons are produced from a pool of precursor cells in the hilus which divide and migrate along radial glia that extend from the hilus to the developing gcl (Schlessinger et al. 1975; Altman and Bayer 1990a, 1990b; Rickmann et al. 1987). This period of time is marked by production of the majority of granule cells as well as by massive cell death (Schlessinger et al. 1975; Gould et al. 1991).

In adulthood, granule cells originate from precursor cells that reside primarily in the subgranular zone (sgz), the region between the $\mathrm{gcl}$ and hilus (Cameron et al. 1993a). We and others have demonstrated that these precursor cells divide and produce daughter cells that differentiate into granule neurons. These cells become incorporated into the gcl and express markers of mature granule neurons, including neuron specific enolase 
(NSE), the calcium binding protein calbindin, the NMDA receptor subunit NR1, and Neuronal Nuclei $(\mathrm{NeuN})$ : within 3 weeks of DNA synthesis (Cameron et al. 1993a, 1993b; Okano et al. 1993; Kuhn et al. 1996). Cells produced in adulthood receive synaptic input and extend axons into the mossy fiber pathway (Kaplan and Hinds 1977; Kaplan and Bell 1984; Stanfield and Trice 1988). Recent studies have shown that this phenomenon is common to many species of mammals. Three shrews, marmosets, macaques, and humans have been shown to produce a substantial number of new hippocampal neurons in adulthood (Gould et al. 1997, 1998, 1999b).

Recent studies performed using the thymidine ana$\log$ bromodeoxyuridine to label proliferating cells, and stereological methods of data analysis have shown that thousands of new cells are produced each day in the dentate gyrus of young and middle-aged adults (Gould et al. 1997, 1998, 1999b). The majority of these cells differentiate into mature neurons (Gould et al. 1997, 1998). In the aged animal, however, the production of new granule neurons diminishes significantly in both the rodent and primate (Kuhn et al. 1996; Gould et al. 1999a).

The substantial number of new granule neurons produced in the adult hippocampal formation and the conservation of this process across mammalian evolution strongly suggests a function for adult-generated neurons. One approach to determining the function of these new neurons is to identify the factors and conditions that regulate their occurrence.

\section{STRESS SUPPRESSES THE PRODUCTION OF HIPPOCAMPAL GRANULE NEURONS: POSSIBLE ROLE OF ADRENAL STEROIDS AND NMDA RECEPTOR-MEDIATED EXCITATORY INPUT}

We have shown that stressful experiences suppress the production of new hippocampal granule neurons in three mammalian species. First, exposure of developing and adult rats to the odors of natural predators, resulted in a significant decrease in the number of hippocampal cells incorporating 3H-thymidine or bromodeoxyuridine in the dentate gyrus (Gould and Cameron 1996; Tanapat et al. 1998). Second, exposure of adult marmosets to resident-intruder stress resulted in a similar effect, diminished production of new hippocampal neurons (Gould et al. 1998). Third, the experience of subordination stress suppresses the formation of new cells in the dentate gyrus of adult tree shrews (Gould et al. 1997). This effect is not transient but rather persists throughout a period of chronic stress as well. Twentyeight days of daily exposure $(1 \mathrm{hr})$ to a dominant tree shrew resulted in a persistent reduction in the number of new granule cells produced (Fuchs et al. 1997). This chronic stress paradigm was associated with a decrease in the volume of the gcl (Fuchs et al. 1997) indicating that a lasting suppression in the addition of new neurons may alter the structure of the dentate gyrus. Because all of these paradigms elevate levels of circulating adrenal steroids, it is possible that the suppressive effects on granule cell production were mediated through activation of the hypothalamic-pituitary-adrenal axis.

Indeed, several lines of evidence indicate that circulating levels of adrenal steroids modulate the production of granule neurons. First, levels of adrenal steroids correlate negatively with the rate of granule cell production. During the first two postnatal weeks in the rat, termed the stress hyporesponsive period, the levels of adrenal steroids are low and the rate of granule cell production is high (Sapolsky and Meaney 1986; Schlessinger et al. 1975). In adulthood, the basal levels of adrenal steroids are relatively high and the rate of granule cell production is relatively low (Gould 1994). Second, we have found that experimental increases in the levels of adrenal steroids result in significant decreases in the rate of granule cell production during development (Gould et al. 1991) and in adulthood (Cameron and Gould 1994). Third, we have found that removal of adrenal steroids stimulates the proliferation of granule cell precursors (Gould et al. 1992), the vast majority of which differentiate into neurons (Cameron and Gould 1994). Collectively, these findings indicate that adrenal steroids naturally suppress the production of granule neurons. However, very few precursor cells in the developing or adult dentate gyrus express either the Type 1 (mineralocorticoid) or Type 2 (glucocorticoid) receptor (Cameron et al. 1993) suggesting that adrenal steroids influence granule cell production indirectly through another factor.

Considerable evidence indicates that adrenal steroids suppress granule cell production by acting through an NMDA receptor-mediated pathway (Cameron et al. 1998). It is likely that these changes in granule cell genesis as a result of pharmacological manipulations of NMDA receptors reflect a natural inhibition of this process by perforant path input because lesion of the entorhinal cortex results in a significant increase in the number of proliferating cells in the dentate gyrus (Cameron et al. 1995). However, our preliminary results indicate that precursor cells do not express the NMDA receptor subunit NR1 (Cameron and Gould 1996), an essential subunit of functional NMDA receptors (Luo et al. 1997), suggesting that NMDA receptor-mediated excitatory input influences granule cell genesis indirectly through an as yet undetermined factor. To date, the factors that directly mediate granule cell production remain undetermined. 


\section{POTENTIAL CANDIDATES FOR FACTORS THAT DIRECTLY REGULATE GRANULE CELL GENESIS: GROWTH FACTORS AND SEROTONIN}

Peptide growth factors have been shown to stimulate mitosis in a variety of different systems. In particular, epidermal growth factor (EGF) and transforming growth factor (TGF $\alpha)$, the endogenous ligand for the EGF receptor in brain, have been shown to act as potent mitogens in a variety of systems (Anchan et al. 1991; Farbman and Bucholz 1996; Yamashita and Oesterle 1995; Zheng et al. 1997). Recent evidence indicates that a significant percentage of the precursor population in the adult dentate gyrus expresses EGF receptors (EGFr) (Okano et al. 1996). Moreover, TFG $\alpha$ is produced at relatively high levels in the adult dentate gyrus and appears to be synthesized by neurons (Wilcox and Derynck 1988; Seroogy et al. 1991). These findings present the possibility that EGF or TGF $\alpha$ is the endogenous factor that directly stimulates the proliferation of granule cell precursors. Recently, we have found that activation of EGFr, by infusion of EGF or TGF $\alpha$ directly into the dentate gyrus, stimulates the proliferation of granule cell precursors (Tanapat and Gould 1997).

\section{SEROTONIN}

Another potential candidate for the direct mediator of granule cell genesis is the neurotransmitter serotonin or 5-hydroxytryptamine (5-HT). Serotonin has been shown to stimulate cell proliferation in nonneuronal systems (Fanburg and Lee 1997; Takuwa et al. 1989). The dentate gyrus is enriched with 5HT1A receptors (Azmitia et al. 1996): and receives serotonergic innervation from the median raphe nucleus of the brainstem (Patel et al. 1996).

A considerable body of evidence suggests that 5HT may stimulate the production of neurons in the dentate gyrus. First, conditions that are associated with diminished granule cell genesis, such as malnutrition (Debassio et al. 1996), aging (Kuhn et al. 1996; Gould et al. 1999), high corticosterone (Cameron and Gould 1994), stress (Gould et al. 1997, 1998), and NMDA receptor activation (Cameron et al. 1995), also decrease the density of 5HT fibers or 5HT1A receptors, or inhibit the release of 5HT in the dentate gyrus (Blatt et al. 1994; Chalmers et al. 1993; McKittrick et al. 1995; Nishimura et al. 1995; Meijer and deKloet 1994; Watanabe et al. 1993; Tao and Auerbach 1996; Whitton et al. 1994; Nyakas et al. 1997). Second, experimental manipulations that stimulate granule cell genesis, such as seizures (Parent et al. 1997), adrenalectomy (Cameron and Gould 1994), and NMDA receptor antagonist treatment (Cameron et al.
1995), also increase the density of 5HT1A receptors or the release of 5HT in the dentate gyrus (Hayakawa et al. 1994; Burnet et al. 1995; Whitton et al. 1994; Kuroda et al. 1994). Third, our preliminary evidence indicates that pharmacological manipulations that elevate 5HT levels in the hippocampus (fenfluramine) or stimulate 5TH1A receptors (8-OH-DPAT) increase the rate of proliferation of granule cell precursors (Jacobs et al. 1998). The majority of these cells differentiate into granule neurons (unpublished observations). It is likely that the stimulatory effect of $5 \mathrm{HT}$ on proliferating cells in the dentate gyrus is not due to an effect of these drugs on adrenal steroids, as drugs which elevate 5HT levels typically increase the levels of circulating corticosterone (Serri and Rasio 1987; Baudrie et al. 1993), a condition that suppresses granule cell genesis (Cameron and Gould 1994). However, it is possible that $5 \mathrm{HT}$ acts downstream of adrenal steroids and NMDA receptors, as NMDA receptor antagonist treatment stimulates the release of 5HT in the brain (Kondoh et al. 1994; Whitton et al. 1994).

Evidence from nonneural systems indicates that EGF and 5HT can exert additive or synergistic actions on cell proliferation (Varrault et al. 1992; Takuwa et al. 1989). Collectively, these data present the possibility that the production of new granule neurons is directly stimulated by activation of EGF or 5HT1A receptors located on granule cell precursors and may be a critical step in the final common pathway in the regulation of this process. Conversely, stress may inhibit granule cell production by activating a pathway that involves glucorticoids, NMDA receptor-mediated excitatory input and ultimately decreases the availability of serotonin or its receptors (Figure 1). Although rapid decreases in the density of hippocampal 5HT1A receptors have been observed following stress, it is interesting to note that different types of stressors have varying effects on 5HT release in the hippocampus (Kirby et al. 1997). Our studies have focused on a small number of species-relevant stressors, all of which inhibit cell proliferation in an acute manner (Gould et al. 1997, 1998; Tanapat et al. 1998). It is possible that other stressors would have different, or no, effects on granule cell production depending on their influence on serotonergic systems. For example, comparison of stressors that stimulate hippocampal serotonin release with those that do not but that downregulate 5HT1A receptors would be particularly instructive.

\section{FUNCTIONAL SIGNIFICANCE OF ADULT- GENERATED HIPPOCAMPAL NEURONS}

The persistence of hippocampal neurogenesis in adulthood raises the important question of what the func- 


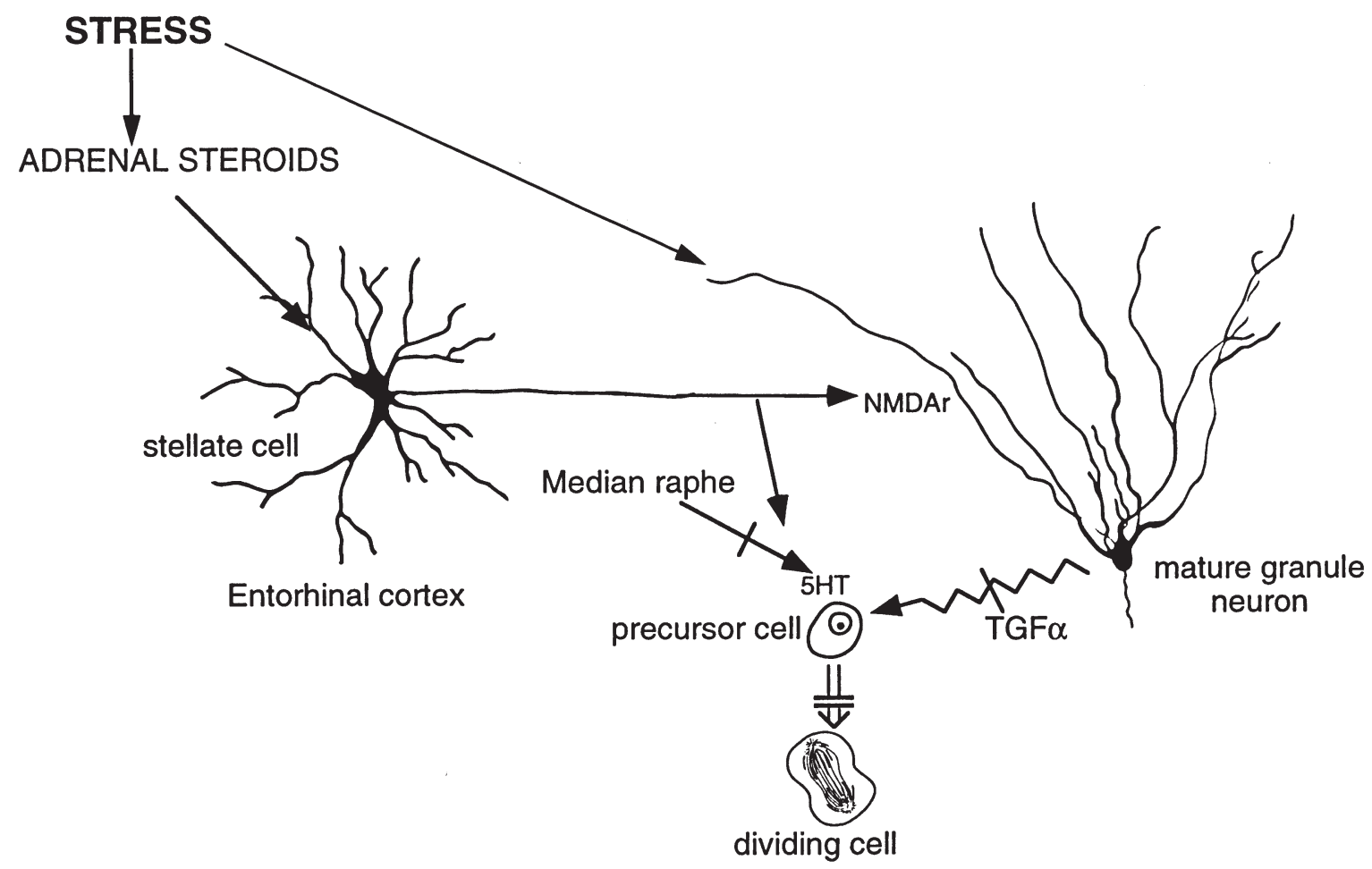

Figure 1. Schematic model demonstrating a possible pathway that regulates stress-induced suppression of granule cell genesis. Stress may have multiple actions on factors that influence cell proliferation, including to increase the levels of circulating adrenal steroids and stimulate glutamate release thus activating NMDA receptors. Activation of this pathway may inhibit two potential mitogenic systems; transforming growth factor alpha and serotonin. Stress may ultimately prevent the release of TGF $\alpha$ from granule neurons and diminish the impact of serotonin by downregulating 5HT1A receptors on granule cell precursors. Under conditions of no stress, both TGF $\alpha$ and serotonin may stimulate granule cell production.

tional significance of adult-generated cells might be. The role of the hippocampal formation in learning and memory has been recognized for decades (Squire and Zola 1996) but the cellular mechanisms that underlie this association remain elusive. Our findings suggest that adultgenerated cells are specifically affected by, and possibly involved in, learning and memory (Gould et al. 1999). Stress-induced suppression of neurogenesis may underlie deficits in learning and memory reported following chronic corticosterone treatment or stress (Bodnoff et al. 1995; Krugers et al. 1997). The extent to which such functional deficits can be prevented by drugs that stimulate granule cell production, e.g., serotonergic agonists, remains undetermined.

\section{REFERENCES}

Altman J, Bayer SA (1990a): Migration and distribution of two populations of hippocampal granule cell precursors during the perinatal and postnatal periods. J Comp Neurol 301:365-381

Altman J, Bayer SA (1990b): Mosaic organization of the hippocampal neuroepithelium and the multiple germinal sources of dentate granule cells. J Comp Neurol 301:325-342
Anchan RM, Angello TA, Balliet A, Walker M (1991): EGF and TGF-alpha stimulate retinal neuroepithelial cell proliferation in vitro. Neuron 6:923-936

Azmitia EC, Gannon PJ, Kheck NM, Whitaker-Azmitia PM (1996): Cellular localization of the 5-HT1A receptor in primate neurons and glial cells. Neuropsychopharmacology 14:35-46

Baudrie V, Oliver C, Chaouloff F (1993): Corticosterone response to the serotonergic agonist $\mathrm{D}$-fenfluramine may be independent from corticotropin-releasing factor (CRF). Neurosci Lett 156:121-124

Blatt GJ, Chen JC, Rosene DL, Volicer L, Galler JR (1994): Prenatal protein malnutrition effects on the serotonergic system in the hippocampal formation: an immunocytochemical, ligand binding and neurochemical study. Brain Res Bull 34:507-518

Bodnoff SR, Humphreys AG, Lehman JC, Diamond DM, Rose GM, Meaney MJ (1995): Enduring effects of chronic corticosterone treatment on spatial learning, synaptic plasticity, and hippocampal neuropathy in young and mid-aged rats. J Neurosci 15:61-69

Burnet PW, Mead A, Eastwood SL, Lacey K, Harrison PJ, Sharp T (1995): Repeated ECS differentially affects rat brain 5-HT1A and 5-HT2A receptor expression. Neuroreport 6:901-904

Cameron HA, McEwen BS, Gould E (1995): Regulation of adult 
neurogenesis by excitatory input and NMDA receptor activation in the dentate gyrus. J Neurosci 15:4687-5692

Cameron HA, Gould E (1994): Adult neurogenesis is regulated by adrenal steroids in the dentate gyrus. Neuroscience 61:203-209

Cameron HA, Gould E (1996): The control of neuronal birth and survival. In Shaw CA (ed), Receptor Dynamics in Neural Development. CRC Press, New York

Cameron HA, Woolley CS, Gould E (1993a): Adrenal steroid receptor immunoreactivity in cells born in the adult rat dentate gyrus. Brain Res 611:342-346

Cameron HA, Woolley CS, McEwen BS, Gould E (1993b): Differentiation of newly born neurons and glia in the dentate gyrus of the adult rat. Neuroscience 56:337-344

Chalmers DT, Kwak SP, Monsour A, Akil H, Watson SJ (1993): Corticosteroids regulate brain hippocampal 5HT1A receptor mRNA expression. J Neurosci 13:914923

Debassio WA, Kemper TL, Tonkiss J, Galler JR (1996): Effect of prenatal protein deprivation on postnatal granule cell generation in the hippocampal dentate gyrus. Brain Res Bull 41:379-383

Fanburg BL, Lee S-L (1997): A new role for an old molecule: serotonin as a mitogen. Am J Physiol 272:795-806

Farbman AI, Bucholz JA (1996): Transforming growth factor-alpha and other growth factors stimulate cell division in olfactory epithelium in vitro. J Neurobiol 30:267280

Fuchs E, Flugge G, McEwen BS, Tanapat P, Gould E (1997): Chronic subordination stress inhibits neurogenesis and decreases the volume of the granule cell layer. Soc Neurosci Abstr 23:317

Gould E (1994): The effects of adrenal steroids and excitatory input on neuronal birth and survival. Ann NY Acad Sci 743:73-93

Gould E, McEwen BS, Tanapat P, Galea LAM, Fuchs E (1997): Neurogenesis in the dentate gyrus of the adult tree shrew is regulated by psychosocial stress and NMDA receptor activation. J Neurosci 17:2492-2498

Gould E, Woolley CS, McEwen BS (1991): Naturally occurring cell death in the developing dentate gyrus of the rat. J Comp Neurol 304:408-418

Gould E, Cameron HA (1996): The regulation of neuronal birth, migration and death in the rat dentate gyrus. Develop Neurosci 18:22-35

Gould E, Cameron HA, Daniels CD, Woolley CS, McEwen BS (1992): Adrenal hormones suppress cell division in the adult rat dentate gyrus. J Neurosci 12:3642-3650

Gould E, Tanapat P, McEwen BS, Flugge G, Fuchs E (1998): Proliferation of granule cell precursors in the dentate gyrus of adult monkeys is diminished by stress. Proc Natl Acad Sci 95:3168-3171

Gould E, Beylin A, Tanapat P, Reeves AJ, Shors TJ (1999a): Hippocampal-dependent enhances adult neurogenesis in the hippocampal formation. Nature Neuroscience 2:260-265

Gould E, Reeves AJ, Fallah M, Tanapat P, Gross CG, Fuchs E (1999b): Hippocampal neurogenesis in adult Old World primates. Proc Natl Acad Sci 96:5263-5267
Hayakawa H, Shimizu M, Nishida A, Motohashi N, Yamawaki S (1994): Increase in serotonin 1A receptors in the dentate gyrus as revealed by autoradiographic analysis following repeated electroconvulsive shock but not imipramine treatment. Neuropsychobiology 30:53-56

Jacobs BL, Tanapat P, Reeves AJ, Gould E (1998): Serotonin stimulates the production of new hippocampal granule neurons via the 5HT1A receptor in the adult rat. Soc Neurosci Abstr 24:1992

Kaplan MS, Bell DH (1984): Mitotic neuroblasts in the 9 day old and 11 month old rodent hippocampus. J Neurosci 4:1429-1441

Kaplan MS, Hinds JW (1977): Neurogenesis in the adult rat: electron microscopic analysis of light radioautographs. Science 197:1092-1094

Kirby LG, Chou-Green JM, Davis K, Lucki I (1997): The effects of different stressors on extracellular 5-hydroxytryptamine and 5-hydroxyindoleacetic acid. Brain Res 760:218-230

Kondoh T, Korosue K, Lee SH, Heros RC, Low WC (1994): Evaluation of monoaminergic neurotransmitters in the rat striatum during varied global ischemia. Neurosurgery 35:278-285

Krugers HJ, Douma BR, Andringa G, Bohus B, Korf J, Luiten PG (1997): Exposure to chronic psychosocial stress and corticosterone in the rat: Effects on spatial discrimination learning and hippocampal protein kinase Cgamma immunoreactivity. Hippocampus 7:427-436

Kuhn HG, Dickinson-Anson H, Gage FH (1996): Neurogenesis in the dentate gyrus of the adult rat: Age-related decrease of neuronal progenitor proliferation. J Neurosci 16:2027-2033

Kuroda Y, Watanabe Y, Albeck DS, Hastings NB, McEwen BS (1994): Effects of adrenalectomy and type I or type II glucocorticoid receptor activation on 5-HT1A and 5-HT2 receptor binding and 5-HT transporter mRNA expression in rat brain. Brain Res 648:157-161

Luo J, Wang Y, Yasuda RP, Dunah AW, Wolfe BB (1997): The majority of N-methyl-D-aspartate receptor complexes in adult rat cortex contain at least three different subunits (NR1/NR2/NR2B). Mol Pharmacol 51:79-86

Mazer C, Muneyyirci J, Taheny K, Raio N, Borella A, Whitaker-Azmitia P (1997): Serotonin depletion during synaptogenesis leads to decreased synaptic density and learning deficits in the adult rat: A possible model of neurodevelopmental disorders with cognitive deficits. Brain Res 760:68-73

McKittrick CR, Blanchard DC, Blanchard RJ, McEwen BS, Sakai RR (1995): Serotonin receptor binding in a colony model of chronic social stress. Biol Psych 37:383-393

Meijer OC, deKloet ER (1994): Corticosterone suppresses the expression of 5-HT1A receptor mRNA in the rat dentate gyrus. Eur J Pharmacol 266:255-291

Nishimura A, Ueda S, Takeuchi Y, Sawada T, Kawata M (1995): Age-related decrease of serotonergic fibres and S-100 beta immunoreactivity in the rat dentate gyrus. Neuroreport 6:1445-1448

Nyakas C, Oosterink BJ, Keijser J, Felszeghy K, de Jong GI, Korf J, Luiten PG (1997): Selective decline of 5-HT1A receptor binding sites in rat cortex, hippocampus and 
cholinergic basal forebrain nuclei during aging. J Chem Neuroanat 13:53-61

Okano HJ, Pfaff DW, Gibbs RB (1993): RB and Cdc2 expression in brain: Correlations with $3 \mathrm{H}$-thymidine incorporation and neurogenesis. J Neurosci 13:2930-2938

Okano HJ, Pfaff DW, Gibbs RB (1996): Expression of EGFR-, p75NGFR, and PSTAIR (cdc2)-like immunoreactivity by proliferating cells in the adult rat hippocampal formation and forebrain. Develop Neurosci 18:199-209

Parent JM, Yu TW, Leibowitz RT, Geschwind DH, Sloviter RS, Lowenstein DH (1997): Dentate granule cell neurogenesis is increased by seizures and contributes to aberrant network reorganization the adult rat hippocampus. J Neurosci 17:3727-3738

Patel TB, Azmitia EC, Zhou FC (1996): Increased 5-HT1A receptor immunoreactivity in the rat hippocampus following 5,7-dihydroxytryptamine lesions in the cingulum bundle and fimbria fornix. Behav Brain Res 73:319323

Rickmann M, Amaral DG , Cowan WM (1987): Organization of radial glial cells during the development of rat dentate gyrus. J Comp Neurol 264:449-479

Sapolsky RM, Meaney MJ (1986): Maturation of the adrenocortical stress response: Neuroendocrine control mechanisms and the stress hyporesponsive period. Brain Res Rev 11:65-76

Schlessinger AR, Cowan WM, Gottlieb DI (1975): An autoradiographic study of the time of origin and the pattern of granule cell migration in the dentate gyrus of the rat. J Comp Neurol 159:149-176

Seroogy KB, Han VK, Lee DC (1991): Regional expression of transforming growth factor-alpha mRNA in the rat central nervous system. Neurosci Lett 125:241-245

Serri O, Rasio E (1987): The effect of d-fenfluramine on anterior pituitary hormone release in the rat: In vivo and in vitro studies. Can J Physiol Pharmacol 65:2449-2453

Squire LR, Zola SM (1996): Structure and function of declarative and nondeclarative memory systems. Proc Nat Acad Sci USA 93:13515-13522

Stanfield BB, Trice JE (1988): Evidence that granule cells generated in the dentate gyrus of adult rats extend axonal projections. Exp Brain Res 72:399-406
Takuwa N, Ganz M, Takuwa Y, Sterzel RB, Rasmussen H (1989): Studies of the mitogenic effect of serotonin in rat renal mesangial cells. Am J Physiol 257:F431-F439

Tanapat P, Galea LAM, Gould E (1998): Stress inhibits the proliferation of granule cell precursors in the developing dentate gyrus. Int J Develop Neurosci 16:235-239

Tanapat P, Gould E (1997): EGF stimulates proliferation of granule cell precursors in the dentate gyrus of adult rats. Soc Neurosci Abstr 23:317

Tao R, Auerbach SB (1996): Differential effect of NMDA on extracellular serotonin in rat midbrain raphe and forebrain sites. J Neurochem 66:1067-1075

Varrault A, Bockaert J, Waeber C (1992): Activation of 5HT1A receptors expressed in NIH-3T3 cells induces focus formation and potentiates EGF effect on DNA synthesis. Mol Biol Cell 3:961-969

Watanabe Y, Gould E, Daniels DC, Cameron H, McEwen BS (1992): Tianeptine attenuates stress-induced morphological changes in the hippocampus. Eur J Pharmacol 222(1):157-162

Watanabe Y, Sakai RR, McEwen BS, Mendelson S (1993): Stress and antidepressant effects on hippocampal and cortical 5-HT1A And 5-HT2 receptors and transport sites for serotonin. Brain Res 615:87-94

Whitton PS, Richards DA, Briggs CS, Fowler LJ (1994): $\mathrm{N}$-methyl-D-aspartate receptors modulate extracellular 5-hydroxytryptamine concentration in rat hippocampus and striatum in vivo. Neurosci Lett 169:215-218

Wilcox JN, Derynck R (1988): Localization of cells synthesizing transforming growth factor-alpha mRNA in the mouse brain. J Neurosci 8:1901-1904

Yamashita H, Oesterle EC (1995): Induction of cell proliferation in mammalian inner-ear sensory epithelia by transforming growth factor alpha and epidermal growth factor. Proc Nat Acad Sci USA 92:3152-3155

Yan W, Wilson CC, Haring JH (1997): 5-HT1a receptors mediate the neurotrophic effect of serotonin on developing dentate granule cells. Dev Brain Res 98:185-190

Zheng JL, Helbig C, Gao WQ (1997): Induction of cell proliferation by fibroblast and insulin-like growth factors in pure rat inner ear epithelial cell cultures. J Neurosci 17:216-226 